\title{
ANÁLISE DE IMAGENS DO SATÉLITE ALOS PALSAR (BANDA L, MODO POLARIMÉTRICO) PARA DISCRIMINAÇÃO DE COBERTURAS DE TERRAS DO DISTRITO FEDERAL
}

\author{
Elaine Marra dos Santos \\ Orientador: Dr. Edson Eyji Sano (UnB) \\ 65 p. - Dissertação (Mestrado) - Defesa 27.03.2009
}

RESUMO. Mapas de cobertura de terras são importantes fontes de dados para monitoramentos ambientais, preservação da biodiversidade, zoneamentos sócio-econômico e ambiental e monitoramento de mudanças climáticas locais e globais, dentre outras atividades. No Distrito Federal (DF), os mapeamentos de cobertura de terras têm sido realizados com base em imagens ópticas. No entanto, imagens de radar constituem-se em uma alternativa viável às imagens ópticas, pois independem das condições de iluminação solar, podem atravessar nuvens e fumaças e podem detectar diferenças nas estruturas da vegetação. 0 objetivo deste estudo é analisar o potencial das imagens de radar adquiridas pelo satélite ALOS PALSAR para 0 mapeamento de cobertura de terras. Uma imagem de 25 de abril de 2007 (banda L, polarizações HH, HV e VV, final da estação chuvosa) de parte do DF foi convertida para coeficientes de retroespalhamento ${ }^{\circ} \delta$ ) e processada por meio da técnica de segmentação por crescimento de regiões. Valores de ${ }^{\circ} \delta$ foram analisados estatisticamente por meio de cluster analysis. Os segmentos foram convertidos para 0 formato shape $\mathrm{e}$ mapeados visualmente na tela do monitor de computador, com suporte de um pacote de programas de sistema de informações geográficas, em uma escala de mapeamento compatível com 1:100.000. As seguintes classes temáticas foram consideradas: Áreas Urbanas consolidadas, Áreas Urbanas em consolidação, Culturas Agrícolas, Pastagens Cultivadas, Reflorestamento, Campos, Cerrado Típico, Matas de Galeria, Matas Indiscriminadas e Reservatórios. A exatidão de mapeamento, fornecido pelo índice kappa e calculado a partir da verificação de 86 pontos em campo, foi de 0,69.

ABSTRACT. Land cover maps are important source of data for environmental monitoring, biodiversity conservation, social, economic and environmental zoning, and local and global climatic changes, among other activities. In the Federal District of Brazil (FD), land cover mappings have been obtained from optical images. However, radar data are valuable alternative for the optical remote sensing since they are independent of solar illumination, can penetrate clouds and smokes and can depict differences in canopy structures. The goal of this study is to analyze the potential of ALOS PALSAR radar data for land cover mapping. A scene covering part of FD, obtained in April 25 $5^{\text {th }}, 2007$ (L-band, HH, HV and VV polarizations, end of wet season) was converted into backscattering coefficients $\left(^{\circ} \delta\right)$ and processed through the image segmentation technique by growing region. Values of ${ }^{\circ} \delta$ were analyzed with the support of cluster analysis. The segments were converted into shape format and mapped visually in the computer screen using a geographical information system software package, in a 1:100,000 mapping scale. The following thematic classes were considered: consolidated urban areas, urban areas in consolidation, croplands, planted pasturelands, reforestations, grasslands, shrub Cerrado, gallery forests, indiscriminated forests and reservoirs. The accuracy of the final map, provided by the kappa index and obtained from 86 field checking points, was 0.69 . 